\title{
Paradox of African Capital Cities: Case Study of global capitalism and urban poor in Lagos and Abuja Capital Cities in Nigeria.
}

\author{
Dr. Mailafiya Aruwa Filaba
}

\begin{abstract}
The Western and Asian methods of studying African capitals suffer from conceptual and methodological problems. The Arabs and colonialists asserted that the beginning of history in Africa started with the coming of Arabs, and that the formation of African elites and urban development were mainly the initiatives of colonial governments. Europeans and Arabs created the notion that African Capitals became internationally significant only with the colonial policies and economy, which in turn enriched and empowered Africans. They did not focus on the much benefits Arabs and colonial governments, the Multi-National Corporations [MNCs] and European private businessmen derived there from the capitals. They over-emphasized the social mobility of the poor and progress of the elite in the cities. Considering the extent of the capitalist activities, African capitals served more the interest of the international communities. Thus, it is equally important to examine for whom the capitals exist.
\end{abstract}

\section{Introduction}

This article has three main objectives. The first one is to review the Western and Asian notions about African Capitals because Europeans and Arabs take credit for initiating the capitals and undermine the initiative abilities and the relative contributions of Africans to the urbanization. European studies in capital cities up with conclusion that a capital city proper is that one modelled along European's, and that only interactions with Europeans informed the pulse and functions of capital cities. The second objective is to stress the significance of capital cities. African cities even before colonization were very popular, and their growths were part and parcel of state-formation (Smith, 1983). They became more important with colonization, which empowered, broadened and developed them. Few more capitals were created since independence. The critical role of the capital cities cannot be over emphasized, as they serve as the nucleus of administration, economic operation, cultural melting pot, and very significantly the ports of global economy. Each capital city is held in pride not only as the symbol of unity, emblem of cultural symbiosis and co-existence but also as symbol of the level of economic development, political and technical sophistry. Indeed, Africa have an "extraordinarily vital importance in the continent's life" more than in any other continent" (Hamdan, 1969). The third objective is to show the problems of African capitals, the capitalist exploitations with particular references to Lagos and Abuja Federal Capitals in Nigeria.

\section{Methodology}

The data here was derived from mainly secondary sources and unpublished dissertations. The inferences and presentation is purely qualitative and comparative.

\section{Results and Discussions}

\section{Conceptual and Methodological Problems in the Study of African Capitals:}

Intellectuals in Europe started to initiate study of Modern African cities in 1954 when the UNESCO conference in Abidjan on the Social Impact of Industrialization and Urbanization in Africa South of the Sahara was hosted. This sparked off other conferences and projects on African urbanization like the 1979 Kampala international conference that consider a variety of urban problems and African urbanization (Miner, 1967). 
Scholars differ on emphasis on which variables are most responsible for the growth of urban areas particularly capital cities. Some Europeans strongly believed that urbanization in the developing world is a response to western modernization, economy and globalization, as the colonial rule set up administrative centres that also became commercial centres. They did not consider the positive contribution of the colonized to the rapid process of urbanization. The methodological and conceptual problems in the study of capital cities are obvious. Some scholars (Pahl, 1966) were pessimistic over ever having an acceptable theory that can explain urbanization, because urbanization is "a complex inter-related system." Any "single reified concept" for it is a mere explanation "in terms of one of its parts." Similarly, Miner (1967) further revealed the disparate perceptions of what constitute urbanization among experts and none was clearly dominant. Urbanism is many sided and it is impossible to find any single definition of the 'city' or 'urbanism' - which would stand up to variety of empirical tests, and which would be appropriate for all sorts of periods and societies (Pahl, 1966). Reismann (1964) thus summed up: "The city is what we choose to make it for the purpose of analysis."

Some scholars came to realize the multi-facet dimension of urbanism, and the conceptual variation among scholars. They then encouraged thematic approaches, which should be disciplines-based perspectives. They edited distinct studies in a single book (Hauser \& Schnore, 1965; Breese, ed 1966). Some of such approaches included "historical aspect of urbanization," political science study of urbanization, economic aspects of urban research, etc. The thematic approaches in these works have the tendency to be materialistic and scientific, highly technical and full of statistics; with glaring problem of over-generalization pulling features of one city that was studied to apply to all.

The earlier scholars were prone to modernization perspective (Oyedele, 1987). It was a bourgeois perspective that understood urbanization to be impact of capitalism, industries, infrastructural development brought about by technology and imperialism. Thus they discussed urbanization in the developing countries with the assumption that it was the impact of colonial policies and economy and by forces outside these countries like the World War II (Breese, 1966). They observed that the colonial administrative centers and infrastructural development were responsible for the gradual increase in the population and migration to towns and cities. This is true to a large extent. Their intent is obviously to show that urbanism started in Europe and later diffused to other continents. They posed that the copied-European urbanism in other continents substituted the traditional culture. They did not realize that the colonized became a symbiosis of European-native culture. Urbanization was 'adaptation of certain European practices' - the European civilization so emulated (Epstein, 1966). African urban centers "are towns built by whites and occupied by blacks" (ibid.). The modernization perspective also approached the urbanization with scale and pace statistics and comparative analysis.

All these studies missed the starting point. They did not consider the scientific evolution of capitals starting from the evolution of settlements as given by Smith (1983). Except the newly created colonial and neo-colonial capitals created overnight, the pre-colonial capital cities evolved through protracted transformation of settlement pattern, economy, socio-political activities and inter-group relations and diplomacy. But the Europeans undermined the roles of pre-colonial capitals, while they were the ones that organized the people and economy, which attracted the Arabs and Europeans to come and participate and later colonize. Colonial rule was the starting point for their analysis of African capitals. Of course, the capitals served the purposes of the imperial and capitalist economy as the following discussion shall reveal.

While some of the studies allude on the fact that the urban centers are fed by rural migrants, the aspect of the economy was not emphasized. Almost all urban centers in Africa are fed by local manufactures and foods from the rural areas. The urban centers are mere exchange centers. Most of the manufactures are purchased from the rural areas and re-traded by the cities' brokers. 
Scholars generally greed that some cities differ in their nature and functions than others in the areas of administration, commerce, investments, security, socialization, development, and so on. It is agreed that cities differ from the countryside or suburbs in terms of the roles they play and their problems like crimes, moral laxity, slums, congestion, sanitation problems, land speculation and conflict over plots, widening gap between the poor and the rich, noises, diseases associated with over-crowding, industrial pollution, and so on.

\section{Evolution of African Capitals}

African political capitals could be approached in the chronological order of their evolution. Handam (1962) utilized this approach. Only that he ran into the problem of hamitic hypothesis and Euro-centric modernization perspective, whereby all the evolution of capital cities in Africa are seen to be the initiatives of Arabs and Europeans. The newly created postcolonial capitals are seen to be responses of diffusion of modernization. Hamdan therefore denigrated pre-colonial capitals. He divided Africa into cultural zones and upheld that the Northern and Eastern African capitals were Arab initiatives, while the rest were European/colonial acts. However, there were relative roles of Arabs and Europeans who linked the immense economic activities and the capitals to the global market for mainly their benefits (Filaba 2007). The capitals can be categorized into four chronological orders below:

\section{Pre-colonial Capitals Inherited by Colonial Governments}

The sources acknowledged that at there were about 20 capitals before colonial conquest, and that Cairo was the most ancient of historic capitals. It was alleged that Cairo was founded by the Fatimid dynasty. The Fatimid ruled Egypt in 969 to 1170 A.D. ( Rodney, 1979). Some scholars believe that Cairo is much older than claimed by the Fatimid, since it had been an urban center where civilization flourished since about 4000 B.C. (Okoye, 1964.) Cairo was once the biggest city in the ancient world (Breese, ed. 1969:148). The next most ancient capital was Tunis, which was prominent as a national capital since the Middle Ages, and serving as entrepote on the Mediterranean Sea . Algiers, like Tunis, got its impetus from the Mediterranean culture. It was Berbers' and the activities of the Turks in the town influenced it to become a capital in 1519 . Rabat was also founded by Almoravids (Jihadists), and have since then remained the capital of Algeria . Hamdan denies it the status of a capital before the French occupation even though he acknowledges the fact that it had been a stronghold ribat (refuge center and secret training abode) of the Almoravids (ibid) Other ones in Eastern Sudan were: Gezira; Senna; El-Damer; Shendi, and Dar-essalaam.

In the horn of Africa, there were Omdurman; Gondar and Addis Ababa. There was Berbera in Somalia. There were also Zanzibar (coast of the Negroes); Mombassa; Malindi and Sofala. Addis Ababa, Zanzibar, Mombassa, Malindi, and Sofala, had been utilized by the Portuguese, as the capital since the $16^{\text {th }}$ century. There was Tananarive in Madagascar, and allegedly founded by Merima of South-East Asian migrants in the Middle Ages (Kimble, 1960).

In West Africa, Hamdam believed that Ibadan had been the capital of Nigeria and was later replaced by Lagos. Ibadan was an entreport with its independent Yoruba speaking people's kingdom before the British conquest in 1860 (Breese, 1966). Ibadan was actually the largest city in the area but not the capital of all the ethnic groups that came to be in the territory named Nigeria . Lagos became a new society with the British conquest in 1860. African elite who competed with the colonial traders and as well struggled for independence emerged here and in Lagos, and influenced political awareness, consciousness of living conditions and imperial exploitation.

\section{Capitals initiated by Colonial Governments}

The colonial governments maintained most of the old capitals and as well created new ones. There were 53 colonial capitals in Africa, which were the following: St. Luis' was created 
as a capital and its role was later shifted to Dakar and was made the capital of Afrique Occidentale Francaise of French West Africa. It was the development of the railways into the inland, which, substituted the waterways and thereby enabled Dakar to substitute St. Luis (D. Whittlesey, 1944:67). Khartoum displaced Omdurman . Hargeisa came to replace Berbera in Somalia. Others included Lourenco Marques (1845), Luanda (1652), Pretoria (1855), Mafeging (1885), Salisbury (1890) in Northern Rhodesia, Kampala (1890), Bulawayo (1893), Etembe (1893), Nairobi (1899), Khartoum (1899), Livingstone (1905), and Geba. The Portuguese later shifted the capital at Geba to Bolama because Geba was intensely infested with malaria. On the account that there was the need for a more densely populated town with heavy economic activities, Geba and Bolama lost their capital status for Bissau Island, which then commanded economic activities of the country.

Grand Bassam was made a capital a capital, and its role was shifted to Bingerville in 1900 due to series of epidemics and plagues. The status was again shifted to Abidjan in 1934. Zinder was the capital of Niger, and was shifted to Niamey in 1926, because Zinder in the desert was not as conducive as Niame in the river-rine area. The capital of Cameron at Buean became "a health resort and a hill station island" that made its access difficult, and thus got the capital moved to Duala, and later to Yaounde Island ( ibid)

Point was made capital of French Congo got its role shifted to Noire Brazzaville in 1929. Boma in 1929 similarly got its role shifted to Leopoldville. Nova Lisboa capital of Angola was similarly shifted the role to Luanda in 1926, because the later was on an "unhealthy" plateau, though in a central location which could have been preferred. Lusaka came to replace Livingstone as capital of Northern Rhodesia in 1935. Laurenco Marques replaced Mocambique as the capital of Mozambique in 1907 (Ibid).

Hamdan noted that some colonies had the propensity of having dual or multiple capitals in one colony. He believed that such style "betray certain rather abnormal features which may well be a manifestation of political anomaly." For instance, Libya had two capitals - Tripoli and Bengazi, both as capitals due to the split of Tripolitania from Cyrenaica Island. The Maghrib (Algria) had five capitals between which the government periodically moved to. They were Rabat as the political capital, Cassablanca as economic capital, Marrakesh as historical capital, Fez as religious capital and Tangier as summer capital. Sudan had Khartoum as modern capital and with Kampala as the economic capital. The Union of South Africa had Cape Town as the seat of the Parliament and Pretoria as the executive seat of executive government. This policy of having two capitals was influenced by the Africaner-Briton dichotomy. Similarly, in South-West Africa , Swakapmund is considered the summer capital, while Windhock is used as assisting capital for few months during winter.

Another phenomenon of capitals unknown elsewhere in the world except Africa was the affair of "borrowed capitals" from another country across the borders. In Nigeria, some local government areas (LGAs) Headquarters in the Niger Delta in the flood prone towns, like in Kogi, Anambra, Imo, Bayelsa, Delata and Rivers States, have the administration shifted to non-flood prone towns in LGAs other than theirs in the rainy seasons. In these cases were: Mauritania administered from St. Louis in Senegal, and Bechuanaland from Mafeking in the Union. Hamdan attributed this aspect of borrowing capitals to the small sizes of the countries and their "lack of any real economic base [sic.]" (Breese,1966).

Hamdan further observed that few of the colonial capitals were inherited "native"/precolonial capitals, while most of the colonial capitals were newly created by the colonial governments. They also had the features of shifts or instability from coastal to more central areas. Some of them were shifted from hilly or disease-prone areas to better areas. Thus, "West Africa in particular is a vast cemetery of dead capitals." The capitals of the Portuguese' colonies, the most ancient colonial capitals in Africa, have been the most unstable. Colonial Africa had more capitals than states - 59 towns have acted as capitals of 32 colonies.

Post Colonial Capitals 
Almost all the post-independence capitals are the inherited colonial capitals. Only six new capitals have been established since 1960 as a result of the emergence of new states and "fiat capitals" or "necessity capitals" were created. For instance, the fissioning of the Afrique Occidentale Francaise led to creation of capitals for the successor states like and Mauritania creates created Kingali and Nouakchott respectively. Bechuana borrowed capital in Mafekin in the Union of South Africa and later developed Serowe.

Another trend of a few African capitals is stagnation and demotion. For instance, Asmara the capital of Eritrea lost its status with the annexation of Eritrea as "Northern Ethiopia" and Hargeisa became the administrative sub-capital of Somalia . Similarly, the dissolution of the Central African Federation, Lusaka the capital of Northern Rhodesia, lost its status to Salisbury the capital of Southern Rhodesia . Libya developed a new federal/national capital at Cyrenaica, and abandoned Tripoli and Bengazi. Due to the excessive elevation, rarefied air and "unhealthy climate" of Addis Ababa , Ethiopia substituted it for Gondar, with moderate elevation from sea level (Breese, p.151). Similarly, Nigeria transferred its federal capital territory from Lagos to Abuja in 1980 (Filaba, 2004).

From the above discussion, relocation of capitals is not a new thing in Africa, and the phenomena are issues of national interest, policy, consideration of economic, ecological, security and other factors. Smith predicted the shift of Capital City from Lagos many years before the policy was promulgated. He argued that the shift of federal capital is a normal historical process as people of a country have propensity for "a reaction against the excessive materialist individualism of their capitals." The Hausa capital at Alkalawa was shifted to Sokoto in the $19^{\text {th }}$ century, and Lagos too, was going to cease to be the capital of Nigeria by the beginning of the third millennium. Leaders and intellectuals in the bid to solve problems of congestion, greed, deplorable economic conditions and declining cultural values in the capitals determine the shift of capitals. He argued that modern technology and imperialism have the tendency to impregnate a commercial capital with the above ills (Usman, 1979). Therefore, we can adduce that the shift of federal capital from Lagos to Abuja was a normal historical phenomenon, and not a prejudice as Lagosians thought and opposed the shift.

This historical "excessive materialism" is a common global phenomenon but in a more rapid process in the developing nations, Lagos on the lead in Africa . Hence, urban analysts like Sovani,.Hauser and Breese analyzed the process using the concept OVER-URBANIZATION. Over-urbanisation of Lagos was characterized by too large population, which could not be supported with employment and available facilities and services. The uncontrolled immigration into Lagos made the population to grow very rapidly beyond its capacity. Thus, the proportion of its total population was higher than expected and beyond what its land and economic capacity could service. (Sovani, 1964; Hauser, 1963; Breese,1966). The UN described overurbanization factor in the developing countries as "the pressure of population on land, but another way of describing the economic underdevelopment that characterizes the cities and their relations to the countryside." Lagos had become very unpopular in the 1970s due to congestion, insecurity, and lack of space for expansion and poor planning of the city. Mabogunje (1968) revealed a vivid example of lack of initiative and policy that could have limited the overpopulation of Lagos. The Population of Lagos between 1851 to 1900 was already full to the brim. This was "the first fifty years of British influence in Lagos , [which] were not years of rapid growth, but consolidation." The British failed to think of planning the Federal Capital Territory along the British capital. Rather, Lagos was stuffed up with freed slaves. As the British resettled freed slaves in Lagos :

Lagos soon became known in the interior as a free colony, and many slaves, having escaped from their masters, made for it. Most of them coming into Lagos before 1865 were from Whydah, Abeokuta, Ibadan, Ijebu. Hausa freed slaves. A large proportion of them were simply declared liberated as apprenticed to artisans, number of slaves who succeeded from time to time in reaching the colony and in thus securing their natural liberty. In 1892, many more slaves 
arrived in Lagos, several of whom were absorbed in the police force (Mabogunje (1968)

This was apart from the heavy influx of Brazilians and freed Africans from the sub-region. Hence, the growth rate of Lagos between 1866 to 1901 was $18 \%$ to $24 \%$ in every ten years. The population of Lagos was about 5000 in $1800 ; 25,083$ in 1866; 28, 518:1871; 37,452:1881; $39,381: 1901$, in a landmass of $6000 \times 6000$ sq. ft. The population of Lagos since 1900 rose vertically in the graph, that by 1980, Lagos' population was about 20 million occupying a landmass of about 30,000 X 30,000 sq. ft. The United Nations Economic Commission for Africa's comparative study of conditions in Leopoldville and Lagos since colonial rule, blamed the governments for allowing the cities to "grow up with no master plan," (Breese, 1966), congestions, excess expenditure, and with many criminals called Area Boys due to unemployment and poverty, that some politicians demanded for relocation of the capital elsewhere (Breese,1966; Albert, 1992; Action Group, 1953; Mabogunje, 1968).

The long and short of it was that Lagos, from a placid settlement by 1800 , got stuffed by 1850 , and became tumultuous and explosive that by 1900 , it was over-urbanized and stymied.

\section{African Capitals and the Wider World}

The commercial and political significance of African capitals attracted Arabs and Europeans who wanted to participate in the trades there, and later forcibly colonized them. Since time immemorial, some cities assumed the status of capitals principally because they were the major commercial centers linking their regions with the long distance trades and trades with outside world. Some of them were also scholarship centers, and the melting pot of cultures. They necessarily attracted migrations from far and wide due to the economic opportunities they offered and due to the fact that life was better there than in the smaller towns and villages. The colonialist used the ancient capitals too an created more, which served as the linking points of Africa with the rest of the world, but also as the centers for the creation of African intellectual, commercial and compradoral bourgeoisie and working class who later envied the monopoly of the colonialists. The capitals thus became the "hot bed of political fermentation" where the countries' bourgeoisie demonstrate their wealth, consciousness and initiatives and struggled to participate, copy and to later replace the colonialists (Breese,1966; Little, 1974; Wilson 1976). That was why they inherited the colonial capitals, and initiated few for political, security and other reasons.

Thus, African political capitals have their global significance so much so that they serve to perpetuate the imperial grab and exploitation of the countries. African capitals were part of colonial economy and politics, and were preferred in allocation of welfare services vis a vis the rural areas, who became attracted by the urban opportunities (Oyedele, 1978; Little; Nnoli, 1979). Colonial development plans were urban-centered, which was the legacy for the post independence politicians.

\section{Poverty of Urban Plans in Africa}

It was observed that the urban development plans are failing due to the tendency of other governments to borrow policies from conventional theories from Europe, which most of them today are no longer valid, integrated to rural economy, and bastardisation of the Master Plans, uncontrolled immigration beyond the cop of the infrastructures, increasing unemployment and Squatter Settlements, mainly government controlled, declining economy and living conditions, and displacing the host community without compensation (Brian, 1973;Morse,1969; Fava, 1968; Kaye,1968; Schorr,1978; Weibourd,1968; Lerner, 1967; Filaba, 2005; Sada \& Oguntoyinbo, 1978).

Some of the governmental policies even worsen the problems of the indigenous communities whose land is being forcibly taken. Industrialization lags far behind the rate of urbanization, so that the migrants in the cities find at best marginal employment. 
University-educated bureaucrat lacking private development capital and an entrepreneurial class, more of their development is governmental, involving foreign economic and technical assistance, requiring an assertive governmental role in international diplomacy. As a consequence of governmental leadership in the development process, public goals have priority over private goals(Berry,1973).

The purposeful rapid urbanization of Abuja without putting in place stringent measures to curb the problems that becloud other cities was an act of ignorance and doing the wrong thing. Urban areas in Nigeria have become congested due to lack of good plans, as: "factories, markets, shops and houses exist side by side, and no zoning. Roads are inadequate. Sanitation is very poor, and electricity and water supplies are very inadequate and unreliable" (Sada \& Oguntoyinbo 1978).

Therefore, the theory of "subsistence urbanization" characterized by people who only "have the bare necessities, and sometimes not even those, for survival in the urban environment, living under conditions even worse than the rural areas" (Breese, 1966) applies on Lagos and Abuja satellite towns, because they are left in squalor. Hence, Abuja is a proof of a neocolonial capitalist city where the gap between the rich and the poor is widening. The original inhabitants were met with injustices and forcibly ejected so that the plots were relocated to the rich and corporate bodies. As a conduit of capitalism, the FCT Abuja is being modernized for the benefit of the construction companies, consultants, and Multinational and Multilateral corporations. The western culture is being super-imposed. Thus, to a remarkable degree, urbanization in newly developing countries is affected by forces outside these countries.

\section{Conclusion}

Evolution of Capital Cities in Africa is as old as civilization, and had immense local and international significance long before colonial conquests. But the colonialists created the notion that the pre-colonial capitals were not significant. In the contrary, colonialism utilized them in order to have proper grip of the colonies, and used them as conduits. Colonial government created more, shifted some, and laid down some infrastructures to facilitate colonial exploitation. African capitals today are planned to facilitate the capitalist and imperial operations. Thus they serve mainly the international communities and companies, using local agents to consolidate their grip of the economy. It is true that urban planners in Africa have failed to bring development to the African masses because the plans never put in place some measures to address urban ills and unforeseen problems, and principally because the plans are foreign and capitalist.

\section{Recommendations}

The planners of urban areas should create urban environment in which there is interrelation between the cities and the suburbs that feed them in order to stimulate rural productivity (Filaba 2005). Lerner warned that no country or urban area can self-sustain its growth by merely consuming, as Abuja is, but also through the "institutional disposition of the full resources" - the agricultural and human potentials. Furthermore, development in the FCT cannot be sustained without modernizing the engulfed rural satellite towns. The rural farmers in the FCT Abuja may adjust to the new urban challenges when only their lives are modernized.

There is the need to put in place the measures to check Urban-Urban and Rural-Urban Migrations. Since the massive migration into Abuja has inherent social ills like Sexually Transmitted Diseases (STDs), HIV/Aids, over-stretch of infrastructures, traffic jam, excessive generation of solid waste disposal, dirt, crimes of all sorts, juvenile delinquency, and so on, government must put measure to these ills. This could be possible by consulting social scientists and historians to draw an orientation program and matrix of problems and solutions to urban ills. (Filaba 2005).

It is the companies and individual businessmen and contractors that are getting fabulously rich in Lagos and Abuja FCT, as the governments use coercive means to seize lands from the rural population to the companies, to the rich individuals and MNCs, thereby making Abuja FCT 
a big central dumping ground of the European and Asian finished goods for easy distribution to other cites of West Africa. Thus, these big beneficiaries of the capital cities should be involved in the development of the cities. Furthermore, governments should adequately compensate respect the fundamental human rights of the host communities whose lands were taken for the development of capital cities.

\section{Bibliography:}

Action Group, (1953) Lagos belongs to the West. London Pwnell \& Sons.

Abdullahi Smith Center, (1983) A Little New Light. ABU Press.

Adeniyi, A. O. (1978) "Administrative Policy Framework for Physical Planning in Nigeria." in Sada P. O. \& J.S. Oguntoyinbo, eds., Urbanization Process and Problems in Nigeria. . Ibadan Uni., pp. 23 - 31

Albert O. (et al), (1992) Urban Management and Urban Violence in Africa. IFRA Ibadan , (2 vol.).

Audu E. (Mrs.) (2000) "Residents bemoan beer palour mushrooming: Authorities plan clampdown as operators insist they constitute nuisance." in Weekly Trust, $21-27$ April 2000, p.21.

Breese G (1966) Urbanization in Newly Developing Countries. Printice Hall Int. Inc.

Breese G. (ed), (1966) The City in Newly Developing Countries: Reading on Urbanism and Urbanization. Prentice Hall.

Brian, (1973) Human Consequences of Urbanization. MacMillan.

Cadwell and Okonjo, (1969) The Population of Tropical Africa. Longmans. Epstein A. L., (1966)

"Urbanization and Social Change in Africa ." In G. Breese, (ed).

Fava S. F., ed. (1968) Urbanism in World Perspective. T. Y. Crowell CO. NY.

Filaba, M.A., (2004) "A History of Karu with Specific Reference to the Consequences of the Rapid Urbanization Process of the Federal Capital City : 1976 - 2002” Ph. D. thesis (unpub.) A.B.U. Zaria.

Filaba, M. A.( 2007) "Arabs in North Africa ." (with Philip Akpen,) in Edited: Hakeem I. Tijani, (ed), Africa and the Wider World. (McGraw-Hill Higher Education Publisher, New York ).

Forde. C. D. ed., (1970) People of the Niger-Benue Confluence: Ethnographic survey of Africa, West Africa . AFRICA PART 10, IAI. London.

Glass R., (1960) Urban Sociology in Great Britain. Oxf. Uni Press.

Gordon Brown, (1960) Year Book and Guide to Southern Africa, Pretoria, pp. 463-465.

Hamdan G. (1962) "The Pattern of Medieval Urbanization in Arab World." World Geography. Vol. 47 Part 2 No, 215, April 1962, pp.130-131

Hauser P. M. \& Leo F. Schnore, eds (1965) The Study of Urbanization, John Willey New York.

Hauser P., (1963) “The Social, Economic and Technological Problems of Rapid Urbanization". In B. F. Hoverlitz \& W. E. Moore, eds., Industrialization and society. Paris, UNESCO.

Horace Miner ed., (1967) The City in Modern Africa. PMO London .

Kaye B., (1968) "Some Residents of Upper Nakin Street, Singapore .” In S. F. Fava, loc. Cit., pp. $471-484$.

Kimble.G.H.T., (1960) Tropical Africa . Vol.1.New York.

Little. K., (1974) Urbanization as a process: An Essay on Movement and Change in Contemporary Africa . R\&KP London.

Lerner D., (1967) “Comparative Analysis of Processes of Modernization.” In Horace Miner, ed., The City in Modern Africa. Pall, London.

Mabogunje A. L., (1968) Urbanization in Nigeria . Uni. London.

Mabogunje A., (1978) "Towards an urban Policy in Nigeria ." in Sada, pp.3 - 6.

Miner M., (1967) The City in Modern Africa . (ed.) Pall Mall Press, London. 
Morse R. M., (1969 ) "Recent Research on Latin American Urbanization: [Marginal Settlements] A Selective Survey with Commentary." In Gerald Breese (ed), pp. 507 - 534

Nnoli O., (1979) Ethnic Politics in Nigeria . $4^{\text {th }}$ Dim. Onitsha, Nigeria .

Ojo A., (1978) "Action Oriented Observation for Urban Development." Sada, pp. 8 - 20.

Okunni, F.(1978) "Government Policy on Housing and Urban Development." In Sada and Oguntoyinbo, pp.1-2

Okoye.M., (1964) The African Response. Bristol.

Oyedele E., (1987) "Colonial Urbanization in Nigeria : Kaduna 1900-1960." Ph.D. thesis, ABU Zaria, Unpubl.

Pahl, R. E. (1966) Reading in Urban Sociology. The Common Wealth International Library.

Reismann R. (1964) The Urban Process. The Free Press, Glentor.

Rodney.W., (1979) How Europe Underdeveloped Africa. Zed Press, Addis Ababa.

Sada P. O. \& J.S. Oguntoyinbo, eds.,(1978) Urbanization Process and Problems in Nigeria. Ibadan Uni.

Scorr A. I., (1978) "How the Poor are House in the Unite States. " in Fava, loc. Cit., pp. 485 - 496

Sovani N. V.,( 1964) "The analysis of Overurbanization.” In Economic Development and Cultural Change. pp.113-122.

Smith Center for Historical Research, (1983) Abdullahi Smith: A Little New Light. CEDDERT, Hanwa Zaria.

Smith A., (1979) "The Contemporary Significance of the Academic Ideals of the Sokoto Jihad." In Y.B.Usman, (ed) Studies in the history of Sokoto Caliphate: Sokoto Seminar Papers. Third Press International, Lagos.

StampL. D., (1953) Africa, A Study in Tropical Development. New York.

Stateman's Year Book, 1960-1961; The Africa of Today and Tomorrow. The Royal African Society, London, p.89

Turner J. F. C., (1969) “Uncontrolled Urban Settlement: Problems and Policies.” In G. Breese, pp. $471-506$.

Udo R. K., (1969) "Population and Politics in Nigeria " in Cadwell

United Nations Economic Commission for Africa, (1969) "Leopoldville and Lagos : Comparative Study of Conditions in 1960." In Gerald Breese, Ed. Pp.436-460.

Weisbourd B., (1968) “Segregation, Subsidies, and Mega polis.” In Fava, pp. 540 - 555

Whittlesey D., (1994) The Earth and the State. Washington.

Wilson G., (1976) An Essay on Economic and Detribalization. ALI Boston. 